\title{
Identification of Rehmannia glutinosa L. NB-ARC family proteins and their typical changes under consecutive monoculture stress
}

\author{
Aiguo Chen ${ }^{1,2}$ (D) $\mathrm{Li} \mathrm{Gu}^{1} \cdot$ Mingjie $\mathrm{Li}^{1,3} \cdot \mathrm{Na} \mathrm{Xu}^{2} \cdot \mathrm{Fajie} \mathrm{Feng}^{1} \cdot$ Guangliang $\mathrm{Liu}^{2} \cdot$ Bao Zhang $^{1} \cdot$ Daping Gong ${ }^{2}$. \\ Junyi Zhang ${ }^{1,4} \cdot$ Hongyan Liu ${ }^{1} \cdot$ Zhongyi Zhang $^{1,3}$
}

Received: 10 July 2017 / Revised: 14 April 2018 / Accepted: 21 April 2018 / Published online: 27 April 2018

(c) The Author(s) 2018

\begin{abstract}
NB-ARC proteins are critical to effector-triggered immunity and play important roles in effector recognition and signal transduction in healthy plant growth. However, their primary protein traits, functions and roles remain incompletely understood in Rehmannia glutinosa. Here, we identified 45 NB-ARC protein sequences from the protein sequence sets and transcriptome of $R$. glutinosa. The CC type was the main one, accounting for $84.44 \%$ of these sequences. The most conserved motif was a 288 aa ADP-binding sequence. This motif belongs to the disease-resistance proteins. Differential expression of 36 expressed $N B-A R C$ genes revealed that $N B-A R C$ genes were rarely expressed 30 days after planting and were frequently expressed approximately 60 days after planting. To further understand the function of NB-ARC in replanted $R$. glutinosa, the genes encoding NB-ARC domains were profiled using qRT-PCR under the different stress states involved in the formation of consecutive monoculture problems. The results showed that $N B-A R C$ genes might play a role in the formation of $R$. glutinosa consecutive monoculture problems. This study is the first to identify NB-ARC genes in $R$. glutinosa and to reveal their roles in consecutive monoculture problems in $R$. glutinosa. These findings provide insights into the mechanism of formation of consecutive monoculture problems.
\end{abstract}

Keywords Rehmannia glutinosa L. C Consecutive monoculture problems · NB-ARC · Expression profile

Communicated by Z.-L. Zhang.

Aiguo Chen and Li Gu have contributed equally to this work.

Electronic supplementary material The online version of this article (https://doi.org/10.1007/s11738-018-2672-1) contains supplementary material, which is available to authorized users.

Zhongyi Zhang

zyzhang@fafu.edu.cn

1 Key Laboratory of Ministry of Education for Genetics, Breeding and Multiple Utilization of Crops, Fujian Agriculture and Forestry University, Fuzhou 350002, China

2 Tobacco Research Institute, Chinese Academy of Agricultural Sciences, Qingdao 266101, China

3 Key Laboratory of Crop Ecology and Molecular Physiology of Fujian Universities, Fujian Agriculture and Forestry University, Fuzhou 350002, China

4 Department of Horticulture, Huaqiao University, Xiamen 361021, China

\section{Introduction}

Consecutive monoculture is the dominant agricultural practice in modern agricultural production due to limited land resources (Lin et al. 2016). However, this mode typically triggers the formation of consecutive monoculture problems, leading to crop yield reduction, quality deterioration, poor growth status, and disease aggravation. The formation of consecutive monoculture problems involves complex interactions among soil-borne diseases, allelochemicals and soil quality deterioration (Zhang and Lin 2009). Consecutive monoculture problems are widespread in crop plant production, especially in medicinal crops.

Rehmannia glutinosa, which belongs to Scrophulariaceae, is an important Chinese medicinal herb. R. glutinosa plants that are cultivated for consecutive years on the same land typically exhibit negative characteristics, including abnormal growth and death during production. Notably, these effects affect only $R$. glutinosa and can persist for 8-10 years before $R$. glutinosa can be replanted (Wen et al. 2001). Given these typical characteristics, $R$. glutinosa 
is an ideal material for studying the mechanism of formation of consecutive monoculture problems ( $\mathrm{Li}$ et al. 2015; Wen et al. 2002). Previous studies have indicated that some biotic and abiotic stress factors involved in the formation of consecutive monoculture problems in R. glutinosa (Tian et al. 2017; Wu et al. 2015). In consecutive monocultures of $R$. glutinosa, root exudates selectively attract pathogenic microbes, which colonize the root surface in consecutive monocultures of $R$. glutinosa. This effect ultimately causes the proliferation of harmful microorganisms in the rhizosphere and induces adverse chemotaxis from "bacterial" to "fungal" types (Wu et al. 2013, 2015, 2016; Zhang et al. 2011; Zhang and Lin 2009). A specific pathogenic Fusarium oxysporum screened from rhizosphere soil microorganisms has been identified as Fusarium oxysporum f.sp. R. gluti$n o s a$. The strain can specifically invade $R$. glutinosa and this has been successfully simulated in the laboratory ( $\mathrm{Wu}$ et al. 2016). Previous studies also screened and identified allelochemicals, such as ferulic acid, from the exudates of rhizosphere in $R$. glutinosa, which successfully induced the characteristics of consecutive monoculture problems in pot experiments (Zhang et al. 2016). Approximately 70 percent of consecutive monoculture problems can in fact be attributed to soil-borne diseases (Sun et al. 2008). The results suggested that the imbalance of the rhizosphere microecology probably is one important cause for the formation of consecutive monoculture problems in $R$. glutinosa. Modern plant immunology and molecular biology studies have showed that pathogen infection is closely related to the false response of host plant immune defence system (Smith et al. 2014; Kushalappa et al. 2016). Previous studies have demonstrated that core biological processes, including DNA replication, RNA transcription and protein translation, are significantly damaged in consecutive monocultures of $R$. glutinosa. The expression of some genes is closely related to fibre root formation and replant disease. In addition, $\mathrm{Ca}^{2+}$, MAPK and ethylene signals and chromatin modification are specifically up-regulated in consecutive monocultures of $R$. glutinosa (Li et al. 2013; Wu et al. 2016; Yang et al. 2013, 2014, 2015). Therefore, we infer that the immune defence system in R. glutinosa could respond incorrectly to consecutive monoculture stress to aggravate abnormal growth and even lead to death.

The plant immune system consists of PTI (pathogen-associated molecular pattern (PAMP)-triggered immunity) and ETI (effector-triggered immunity) (Jones and Dangl 2006; Stael et al. 2015). The pattern recognition receptors (PRRs) of PTI systems act on the cytomembrane and can recognize conserved PAMP features of different species or genera. The receptors of ETI systems located in the cytoplasm can specifically and robustly respond to pathogen effectors through NB-LRR (nucleotide-binding-leucine-rich repeat) domain-mediated perception (Bigeard et al. 2015; Dodds and Rathjen 2010; Groll et al. 2008; Marone et al. 2013; Thomma et al. 2011). NB-LRR mainly consists of a carboxy-terminal LRR domain, NB-ARC (nucleotide-binding adaptor shared by APAF-1, R proteins, and CED-4) and amino-terminal TIR (toll/interleukin-1 receptor/coiled coil) or CC domains. LRRs are important for effector recognition, and TIR/CC transmits signals of pathogen invasion to downstream proteins, including EDS (enhanced disease susceptibility) and NDR (non-race-specific disease resistance), to induce a hypersensitive response (Ma et al. 2013). In the plant immune response to effectors derived from invading pathogens, NB-LRR domians determine whether the ETI can be properly initiated (Gassmann and Bhattacharjee 2012; Pajerowska-Mukhtar et al. 2013). NB-ARC proteins are encoded by numerous polymorphic $R$ family genes (Yue et al. 2011), whereas the protein properties of NB-ARC and their response mechanisms in consecutive monocultures of $R$. glutinosa remain largely unknown. Here, we identified $R$. glutinosa NB-ARC proteins and analysed their differential expression profiling at different developmental stages. The stress factors involved in the formation of consecutive monoculture problems in $R$. glutinosa were used to assess the roles of NB-ARC proteins in consecutive monoculture problems. These findings provide valuable information for understanding the roles of NB-ARC in the formation of consecutive monoculture problems.

\section{Materials and methods}

\section{Plant materials and treatments}

Field experiments with $R$. glutinosa 'Wen 85-5' were arranged at the Wenxian Agricultural Institute in Jiaozuo City, Henan Province, China. One group of seedlings was grown in a field where $R$. glutinosa had not been planted for more than 10 years. Another group was grown in a field where the same cultivar had been grown the previous year (planted on April 20 and harvested on November 27, 2012). For convenience of description, we refer to the former group as first-year plants (FP) and the latter group as second-year plants (SP). The tuberous roots of $R$. glutinosa used for cultivation in two groups were planted with the density of 30 $\mathrm{cm} \times 30 \mathrm{~cm}$ on April 10, 2013. A total of 2000 plants were contained in each group. Fields were maintained with locally normal production conditions. The fresh tuberous roots were collected, respectively, at 30,60, 90, 120, and 150 days after planting, and six plants were taken at each time. Each plant was regarded as a biological replicate. All samples mentioned above were immediately frozen in liquid nitrogen and stored at $-80{ }^{\circ} \mathrm{C}$ until use.

Pot experiments were performed under controlled conditions $\left(28^{\circ} \mathrm{C}, 10,000 \mathrm{~lx}\right)$ at the Institute of GAP for Chinese 
Medicinal Materials, Fujian Agriculture and Forestry University. $R$. glutinosa "wen $85-5$ " was grown in plastic pots of $25 \mathrm{~cm}$ diameter and $22 \mathrm{~cm}$ height. Four treatments, including first-year planting (FP), second-year planting (SP), ferulic acid chemigation (FA), and invasion of Fusarium oxysporum [FO, identified as Fusarium oxysporum f.sp. R. glutinosa (Wu et al. 2016)], were conducted, and each treatment was assessed in ten pots. The soil used in the FP, FA and FO treatments was collected from land where $R$. glutinosa had not been planted for at least the last 10 years, and the soil used in the SP treatment was collected from land where $R$. glutinosa had been planted in the previous year. Each treatment was conducted as follows. For the FA treatment, FA solution was used for watering until a negative appearance was noted that was similar to the appearance caused by consecutive monoculture problems. In total, $60 \mathrm{ml}$ of FA solution was poured each time in a pot, and the final concentration was $10 \mathrm{mmol} \mathrm{L}^{-1}$ (the FA concentration gradient was from 0.3 to $10 \mathrm{mmol} \mathrm{L}^{-1}$ in 30 days). For the FO treatment, $F$. oxysporum strains were isolated from the infected $R$. glutinosa tuberous roots and cultured in $100 \mathrm{ml}$ of potato dextrose broth (PDB) in $250 \mathrm{ml}$ Erlenmeyer flasks for 4-5 days at $24{ }^{\circ} \mathrm{C}$, without shaking and in darkness. The mycelia were filtered from the PDB and washed three times with sterile, distilled water. Conidial suspensions of $F$. oxysporum f.sp. $R$. glutinosa were prepared from 5-day-old cultures in PDB, followed by filtering through four layers of cheesecloth and diluting to $1 \times 10^{6}$ conidia/ml with sterilized water. FO suspension solution was irrigated until disease symptoms appeared. The amount of FO solution added to a pot was $60 \mathrm{ml}$ each time. The FP and SP treatments were irrigated with the same volume plain water $(60 \mathrm{ml})$ and assessed 60 days after planting. Each treatment was photographed, and fresh tuberous roots were then collected and stored at $-80{ }^{\circ} \mathrm{C}$ after being frozen by liquid nitrogen for qRT-PCR.

\section{Identification of $R$. glutinosa NB-ARC proteins}

To identify $R$. glutinosa-specific NB-ARC proteins, HMM files (PF00931) that characterized the conserved properties of the NB-ARC structure were extracted from the Pfam 31.0 database (http://pfam.xfam.org/). HMMER suite (v3.1b2, Finn et al. 2015) was used to identify candidate NB-ARC proteins in the $R$. glutinosa database translated from the $R$. glutinosa transcriptome based on the HMM files. NB-ARC proteins were further analysed using TMHMM (http://www. cbs.dtu.dk/services/TMHMM/) and PSORT software (http:// psort.hgc.jp/form.html) to predict the transmembrane and subcellular localization, respectively. The proteins located in the cytoplasm with loss of transmembrane structure were identified as candidate NB-ARC proteins. The genes encoding NB-ARC proteins were simultaneously screened from the $R$. glutinosa transcriptome database (Li et al. 2017).
NB-ARC functions were further confirmed based on annotation information from the $\mathrm{Nr}$ (NCBI non-redundant protein sequences, http://www.ncbi.nlm.nih.gov/), GO (Gene Ontology, http://www.geneontology.org/) and KEGG (Kyoto Encyclopedia of Genes and Genomes, http://www.genom e.jp/kegg/) databases.

\section{Protein structure and phylogenetic analysis}

The conserved motifs of $R$. glutinosa NB-ARC proteins were identified using the online SMART tool (MarchlerBauer et al. 2017) and depicted using IBS 1.0.1 software (Liu et al. 2015). The secondary structures of the NB-ARC proteins were identified using DNAMAN8.0 software (Lynnon BioSoft, Quebec, Canada). The tertiary structures of the NB-ARC proteins were analysed based on homology modelling methods using the online SWISS-MODEL software (http://www.swissmodel.expasy.org/) and were displayed using SPDBV 4.10 software (Guex and Peitsch 1997). Phylogenetic relationships among candidate NB-ARC proteins were constructed based on the neighbour-joining method and bootstrap method (1000 replicates) using MEGA6.06 software (Tamura et al. 2013).

\section{Expression profile analysis of NB-ARC genes}

Total RNA in field experiment was extracted from the tuberous root using TRIzol reagent (Invitrogen) according to the manufacturer's protocol and treated with DNase I (Qiagen) to degrade any possible DNA contamination. $6 \mu \mathrm{g}$ total RNA was treated with oligo-(dT) magnetic beads to purify the mRNA. The mRNA was then fragmented into short (100-200 bp) pieces using moderate divalent cations under high-temperature conditions. These fragments were reverse transcribed into the cDNA first strand with a random hexamer primer, followed by cDNA second strand generation using DNA polymerase I. The cDNA fragments were enriched using PCR amplification and then purified using magnetic beads. The library products were sequenced on the Illumina HiSeq ${ }^{\mathrm{TM}} 2000$ (Beijing Genomics Institute, Shenzhen, China). After quality control (QC) and further filtration, the clean reads were mapped onto the RNA-Seq reference sequence using the BWA software (Kobayashi et al. 2014). Sequence alignment was controlled in no more than 2 bp mismatches. The gene expression level was calculated using the RPKM (Reads Per Kilobase of transcript per Million mapped reads) method (Mortazavi et al. 2008). The threshold of "FDR (False Discovery Rate) $\leq 0.001$ and the absolute value of $\log _{2}$ Ratio (Ratio $=$ RPKM of SP/RPKM of FP) $\geq 1$ " was used to assess the significance of the gene expression differences. In $45 N B$-ARC genes aligned from the $R$. glutinosa transcriptome library, 36 differentially expressed $N B-A R C$ genes were used in the following studies based on the expression profiling. A differential expression heatmap of 
identified genes was analysed via the hierarchical clustering method using MeV 4.9.0 tool (Saeed et al. 2006).

\section{RNA isolation and reverse transcription}

Total RNA in pot experiment was extracted from different samples of fresh $R$. glutinosa. Approximately $50 \mathrm{mg}$ of tissue was collected and subjected to RNA extraction using TRIzol reagent (Invitrogen). Total RNA samples were treated extensively with RNase-free DNase I (Invitrogen) to remove any contaminating genomic DNA. RNA concentration was measured using a spectrophotometer, and RNA integrity was ensured via analysis on a $1.5 \%(w)$ agarose gel. First strand cDNA was synthesized in a $20 \mu \mathrm{L}$ of mixture containing $2 \mu \mathrm{g}$ of total RNA, $2 \mu \mathrm{L}$ of $50 \mu \mathrm{M}$ oligo-(dT)12-18 primers, $1 \mu \mathrm{L}$ of RNase inhibitor and $1 \mu \mathrm{L}$ of $40 \mathrm{U} / \mu \mathrm{L}$ M-MLV reverse transcriptase (Invitrogen). The mixture was incubated at $37^{\circ} \mathrm{C}$ for $50 \mathrm{~min}$ and then heated to $70{ }^{\circ} \mathrm{C}$ for $15 \mathrm{~min}$.

\section{qRT-PCR analysis}

For qRT-PCR, NB-ARC PCR primers (Additional file 1) were designed using Beacon designer 8.0 software (Premier Biosoft International, Palo Alto, CA, USA). A fragment of gene encoding 18S rRNA (Additional file 1) was used as a reference. PCR was performed using a Bio-Rad IQ5 instrument (Bio-Rad, Hercules, CA, USA) based on SYBR Green to detect transcript abundance. Each $25 \mu \mathrm{L}$ of reaction contained $0.5 \mu \mathrm{M}$ of each primer and approximately $0.5 \mathrm{U}$ enzymes, cDNA and SYBR Green. Negative control reactions contained no cDNA. Fivefold dilutions of the cDNA template were tested under identical conditions. The PCR programme included an initial denaturing step $\left(95^{\circ} \mathrm{C}\right.$ for $\left.10 \mathrm{~s}\right) ; 40$ cycles at $95^{\circ} \mathrm{C}$ for $5 \mathrm{~s}, 60^{\circ} \mathrm{C}$ for $10 \mathrm{~s}$, and $72{ }^{\circ} \mathrm{C}$ for $15 \mathrm{~s}$; and a final stage at $55-95{ }^{\circ} \mathrm{C}$ to determine the dissociation curves of the amplified products. All reactions were at least replicated for three times. The data were analysed using Bio-Rad IQ5 Optical System Software v2.1. The data were normalized on the basis of the 18S rRNA threshold cycle $(\mathrm{Ct})$ value. The samples in the FP treatment were used as controls, and their normalized $\mathrm{Ct}$ values were set to 1 . The relative gene expression of the SP, FA and FO was calculated using the $2^{-\Delta \Delta C T}$ method (Livak and Schmittgen 2001). The expression data of the different treatments were statistically analysed with SAS 9.1 statistical software using one-factor ANOVA and Duncan multiple comparisons.

\section{Results}

\section{Identification of the NB-ARC protein family in $R$. glutinosa}

A set of $68 \mathrm{NB}-\mathrm{ARC}$ protein sequences were separated from the $R$. glutinosa protein sequence sets obtained from our previous study using the Hidden Markov model method (Li et al. 2017). Subsequently, 45 sequences were further confirmed in $\mathrm{Nr}$ and KEGG using blastp. To assess the NB-ARC homology with other species, $R$. glutinosa NBARC sequences were aligned using the NCBI database, resulting in 19 sequences highly homologous (38-89\%) to Sesamum indicum, 21 sequences highly homologous (51-85\%) to Erythranthe guttata, and 5 sequences highly homologous (45-59\%) to Nicotiana tomentosiformis, Capsicum annuum, Arachis ipaensis, Nicotiana tabacum and Cynara cardunculus (Table 1). Further functional annotation on basis of KEGG and GO analyses of the candidate NB-LRR proteins revealed that all sequences were resistance proteins involved in the interaction between plant and pathogen (Additional files 2, 3).

\section{Protein structure analysis of the NB-ARC sequences in $R$. glutinosa}

In general, NB-ARC proteins in the ETI system typically lack a transmembrane region. To assess the subcellular localization of $45 \mathrm{NB}-\mathrm{ARC}$ sequences, the corresponding transmembrane trait was predicted using the online TMHMM server 2.0 and PSORT software. As a result, all candidate NB-LRR proteins were located in the cytoplasm and lacked a transmembrane region.

According to the prediction, the conserved domains of the $45 \mathrm{NB}-\mathrm{ARC}$ sequences and their lengths are presented in Fig. 1a. In total, 45 NB-ARC sequences contained at least one conserved domain of LRR, NB-ARC or TIR/CC. Of these, seven proteins, including CL343.Contig1_All, CL4723.Contig1_All, CL6508.Contig2_All, CL6748. Contig1_All, CL7829.Contig2_All, Unigene907_All and Unigene12365_All, contained NB-ARC, LRR and TIR/ CC. NB-ARC sequences with a CC type amino terminal were the main type, accounting for $84.44 \%$ of the total NB-ARC sequences. Moreover, the 45 NB-ARC sequence lengths ranged from 195 to 1310 aa.

Based on the conserved motifs in the NB-ARC domain (Additional file 4), an ADP (adenosine diphosphate)-binding element of 288 aa in length was the most conserved motif, containing $12 \alpha$-helixes and $4 \beta$-strands. Of these structures, 4 parallel $\beta$-strands located at Ser24-Gly30, Leu55-Val61, Leu105-Asp109, and Ile135-Thr139 in the 
Table 1 NB-ARC family proteins identified in the $R$. glutinos $a$ transcriptome

\begin{tabular}{|c|c|c|}
\hline Gene ID & $\begin{array}{l}\text { Amino acid } \\
\text { length (aa) }\end{array}$ & Blast results (query cover, $E$ value, identities, accession no., description, [species]) \\
\hline L343.Contig1_All & 1310 & 100\%, 0, 79\%, XP_011089052.1, disease resistance protein At3g14460 [Sesamum indicum] \\
\hline CL698.Contig4_All & 476 & $\begin{array}{l}\text { 100\%,9E-166, 59\%, XP_012841530.1, late blight resistance protein homologue R1A-3 [Erythranthe } \\
\text { guttata] }\end{array}$ \\
\hline CL788.Contig4_All & 760 & 99\%, 0, 64\%, XP_012854094.1, disease resistance protein RGA4 [Erythranthe guttata] \\
\hline CL1151.Contig3_All & 626 & 100\%, 0, 60\%, XP_012857645.1, late blight resistance protein homologue R1A-3 [Erythranthe guttata] \\
\hline CL1654.Contig1_All & 854 & 99\%, 0, 59\%, XP_012853175.1, late blight resistance protein homologue R1A-3 [Erythranthe guttata] \\
\hline CL3079.Contig2_All & 489 & $\begin{array}{l}\text { 100\%, 1E-179, 59\%, XP_012853244.1, late blight resistance protein homologue R1A-10 isoform X2 } \\
\text { [Erythranthe guttata }]\end{array}$ \\
\hline CL4021.Contig1_All & 519 & 100\%, 2E-162, 50\%, XP_009617577.1, disease resistance protein At5g66900 [Nicotiana tomentosiformis \\
\hline CL4439.Contig1_All & 233 & $100 \%, 2 \mathrm{E}-110,71 \%, \mathrm{XP} \_012854177.1$, disease resistance protein RGA1 [Erythranthe guttata] \\
\hline CL4447.Contig1_All & 862 & 99\%, 0, 88\%, XP_011080937.1, uncharacterized protein LOC105164077 [Sesamum indicum] \\
\hline CL4723.Contig1_All & 888 & 100\%, 0, 85\%, XP_012855653.1, late blight resistance protein homologue R1A-10 [Erythranthe guttata] \\
\hline CL6508.Contig2_All & 891 & 100\%, 0, 88\%, XP_011070823.1, late blight resistance protein homologue R1B-17 [Sesamum indicum] \\
\hline CL6748.Contig1_All & 811 & 100\%, 0, 63\%, XP_012849297.1, disease resistance protein RPM1-like isoform X1 [Erythranthe guttata] \\
\hline CL7604.Contig1_All & 306 & 100\%, 2E-119, 60\%, XP_011098143.1, disease resistance protein RPM1-like [Sesamum indicum] \\
\hline CL7774.Contig1_All & 867 & 100\%, 0, 59\%, XP_012829248.1, late blight resistance protein homologue R1A-3 [Erythranthe guttata] \\
\hline CL7829.Contig2_All & 918 & 100\%, 0, 88\%, XP_011073815.1, disease resistance protein At1g50180 [Sesamum indicum] \\
\hline CL8221.Contig1_All & 268 & 98\%, 3E-51, 38\%, XP_011078622.1, disease resistance protein At1g50180 [Sesamum indicum] \\
\hline CL8782.Contig1_All & 610 & 100\%, 0, 59\%, XP_012855535.1, late blight resistance protein homologue R1A-10 [Erythranthe guttata] \\
\hline CL9919.Contig1_All & 721 & 99\%, 0, 65\%, XP_012853175.1, late blight resistance protein homologue R1A-3 [Erythranthe guttata] \\
\hline CL10007.Contig4_All & 195 & $\begin{array}{l}\text { 100\%, 4E-68, 61\%, XP_012856179.1, late blight resistance protein homologue R1B-16 [Erythranthe } \\
\text { guttata] }\end{array}$ \\
\hline Unigene283_All & 327 & 100\%, 0, 85\%, XP_011070551.1, late blight resistance protein homologue R1B-14 [Sesamum indicum] \\
\hline Unigene907_All & 935 & 100\%, 0, 73\%, XP_011072600.1, disease resistance protein RGA2-like [Sesamum indicum] \\
\hline Unige & 443 & $\begin{array}{l}\text { 100\%, 2E-172, 55\%, XP_016547057.1, disease resistance protein TAO1-like isoform X2 [Capsicum } \\
\text { annuит] }\end{array}$ \\
\hline Unige & 539 & 100\%,9E-180, 51\%, XP_012833863.1, disease resistance RPP13-like protein 3 [Erythranthe guttata] \\
\hline Unig & 217 & tein RGA1 [Sesamum indicum] \\
\hline Unigene4345_All & 535 & 100\%, 0, 81\%,XP_011080807.1, disease resistance RPP13-like protein 2 [Sesamum indicum] \\
\hline Unigene4363_All & 901 & 99\%, 0, 59\%, XP_011091324.1, disease resistance protein At1g58602 [Sesamum indicum] \\
\hline Unigene6172_All & 247 & $\begin{array}{l}\text { 98\%, 2E-122, 73\%, XP_011083960.1, late blight resistance protein homologue R1A-10 isoform X2 } \\
\text { [Sesamum indicum }]\end{array}$ \\
\hline Unigene6303_All & 226 & $\begin{array}{l}\text { 100\%, 3E-107, 72\%, XP_011089745.1, late blight resistance protein homologue R1A-10 [Sesamum } \\
\text { indicum }]\end{array}$ \\
\hline Unigene7113_All & 722 & 99\%, 0, 56\%, XP_012829191.1, late blight resistance protein homologue R1A-10 [Erythranthe guttata] \\
\hline Unigene7646_All & 626 & 99\%, 0, 59\%, XP_012857645.1, late blight resistance protein homologue R1A-3 [Erythranthe guttata] \\
\hline Unigene7647_All & 619 & 100\%, 0, 61\%, XP_012857645.1, late blight resistance protein homologue R1A-3 [Erythranthe guttata] \\
\hline Unigene7657_All & 794 & 100\%, 0, 58\%, XP_012829191.1, late blight resistance protein homologue R1A-10 [Erythranthe guttata] \\
\hline Unigene9801_All & 435 & 100\%, 5E-124, 45\%, XP_016178697.1, disease resistance protein RGA3 [Arachis ipaensis] \\
\hline Unigene10109_All & 334 & $\begin{array}{l}\text { 100\%,5E-118,56\%, XP_012847840.1, late blight resistance protein homologue R1A-3 [Erythranthe } \\
\text { guttata] }\end{array}$ \\
\hline Unigene12365_All & 1183 & 99\%, 0,63\%, XP_011088145.1, disease resistance protein RGA3 [Sesamum indicum] \\
\hline Unigene12477_All & 820 & 100\%, 0, 89\%, XP_011083793.1, disease resistance protein At4g33300 [Sesamum indicum] \\
\hline Unigene13465_All & 873 & 100\%, 0, 68\%,XP_011079215.1, disease resistance RPP13-like protein 1 [Sesamum indicum] \\
\hline Unigene13744_All & 251 & 99\%, 5E-98, 59\%, XP_016512278.1, disease resistance protein TAO1-like [Nicotiana tabacum] \\
\hline Unigene17274_All & 424 & 100\%, 0, 83\%, XP_012850882.1, disease resistance protein At4g27220 [Erythranthe guttata] \\
\hline Unigene21268_All & 252 & $\begin{array}{l}\text { 100\%, 1E-86, 60\%, XP_011072560.1, late blight resistance protein homologue R1A-3 [Sesamum indi- } \\
\text { cum }]\end{array}$ \\
\hline Unigene23508_All & 220 & 100\%, 1E-49, 45\%, KVH92583.1, disease resistance protein [Cynara cardunculus var. scolymus] \\
\hline Unigene25475_All & 889 & 99\%, 0, 53\%, XP_011071970.1, late blight resistance protein homologue R1A-10 [Sesamum indicum] \\
\hline
\end{tabular}


Table 1 (continued)

\begin{tabular}{|c|c|c|}
\hline Gene ID & $\begin{array}{l}\text { Amino acid } \\
\text { length (aa) }\end{array}$ & Blast results (query cover, $E$ value, identities, accession no., description, [species]) \\
\hline Unigene25774_All & 722 & 99\%, 0, 56\%, XP_012829191.1, late blight resistance protein homologue R1A-10 [Erythranthe guttata] \\
\hline Unigene26135_All & 877 & 99\%, 0, 51\%, XP_011091064.1, late blight resistance protein homologue R1B-16 [Sesamum indicum] \\
\hline Unigene26472_All & 375 & $\begin{array}{l}\text { 100\%, 7E-163, 63\%, XP_012856361.1, late blight resistance protein homologue R1B-17 [Erythranthe } \\
\text { guttata] }\end{array}$ \\
\hline
\end{tabular}

NB-ARC domain sequence enclosed the core barrel structure of the subunit (Fig. 1b).

\section{Phylogenetic analysis of the R. glutinosa NB-ARC proteins}

To identify the NB-ARC sequence domains of $R$. glutinosa and their homology with Arabidopsis thaliana, an unrooted phylogenetic tree was constructed using sequence alignment via the neighbour-joining method. In total, the 45 candidate sequences were divided into 6 groups. Of these, group VI included $25 \mathrm{NB}-\mathrm{ARC}$ proteins with relatively complete ARC motifs. Groups I, II, IV and V consisted of six, two, four and seven proteins, respectively. Group III had only one sequence (Fig. 2a). These data were consistent with stable binding of 12 LRR monomers, which require longer NBARC domains (Ma et al. 2013).

Rehmannia glutinosa NB-ARC sequences were also aligned with Arabidopsis thaliana sequences. Eighteen homologous NB-ARC protein sequences were present in $R$. glutinosa. Highly conserved motif traits and similar protein functions were presented according to the node on the phylogenetic tree. Of these proteins, six NB-ARC proteins, Unigene17274_All, Unigene2179_All, CL7829. Contig2_All, CL343.Contig1_All, Unigene13465_All, and Unigene9801_All, in $R$. glutinosa exhibited high similarity with six NB-ARC proteins, AT4G27220.1, AT4G27190.1, AT4G09360.1, AT3G14470.1, AT3G14460.1 and AT1G50180.1, in Arabidopsis thaliana (Fig. 2b).

\section{Expression of NB-ARC genes at different developmental stages in FP and SP R. glutinosa}

The gene expression pattern can provide important clues regarding gene function. To clarify the response characteristics of $N B-A R C$ genes in consecutive monocultures of $R$. glutinosa, $45 \mathrm{NB}-A R C$ genes were matched from the $R$. glutinosa differential expression profiles using RNA-Seq. The expression profiles were evaluated using Euclidean distance hierarchical clustering (Fig. 3a, b, additional file 5).

According to the $R$. glutinosa $N B-A R C$ gene expression profiles in response to two treatments of FP and SP, 36 expressed genes could be divided into three groups (Fig. 3a, additional file 5). Groups I (Unigene12477_All and Unigene
907_All) and II (Unigene 25475_All and CL4439.Contig1_ All) contained two genes respectively, all of which presented higher expression abundance in comparison to other group during entire growth period of FP and SP treatments. The other genes belonged to group III had the characteristics of lower sustained expression ability. Most of the $N B-A R C$ genes were up-regulated in consecutive monocultures of $R$. glutinosa (Fig. 3b, additional file 5). The results indicated that consecutive monoculture stress mediates increased expression of $N B-A R C$ genes in the ETI system.

Among the $N B-A R C$ genes expressed at the SP1-SP5 developmental stages in consecutive monocultures of $R$. glutinosa, the up-regulated genes accounted for 8.33, 91.67, $38.89,66.67$ and $97.22 \%$, respectively. $N B-A R C$ genes were rarely expressed in the SP1 stage (1-30 days after planting) under consecutive monoculture stress, whereas $N B-A R C$ genes were frequently expressed in the SP2 (31-60 days after planting) and SP5 (121-150 days after planting) stages. The changes were consistent with normal growth at the SP1 stage and large-scale plant deaths during the SP2 stage in consecutive monocultures of $R$. glutinosa.

Therefore, the SP2 might represent a critical developmental stage in which the immune resistance balance maybe altered in response to pathogen invasion, and the seedling stage may represent a key stage for the formation of the immune resistance system.

\section{Expression profiles of $N B-A R C$ genes under different stress factors involved in the formation of consecutive monoculture problems}

To identify $N B-A R C$ genes involved in the formation of consecutive monoculture problems in response to different stress factors, an in vitro test experiment was conducted under SP, FA, and FO stresses. Expression profiles of different stress factors are presented in Fig. 4. Pearson's correlation coefficients are shown in Table 2.

Compared with the FP control, each treatment caused an abnormal growth phenomenon (Fig. 4a). For different stress factors, FO and FA treatments significantly increased the expression of nine $N B-A R C$ genes, and five of the nine $N B$ $A R C$ genes exhibited increased expression upon SP treatment compared with FA (Fig. 4b). Significant positive correlation was only between FO and SP treatments (Table 2). 
a

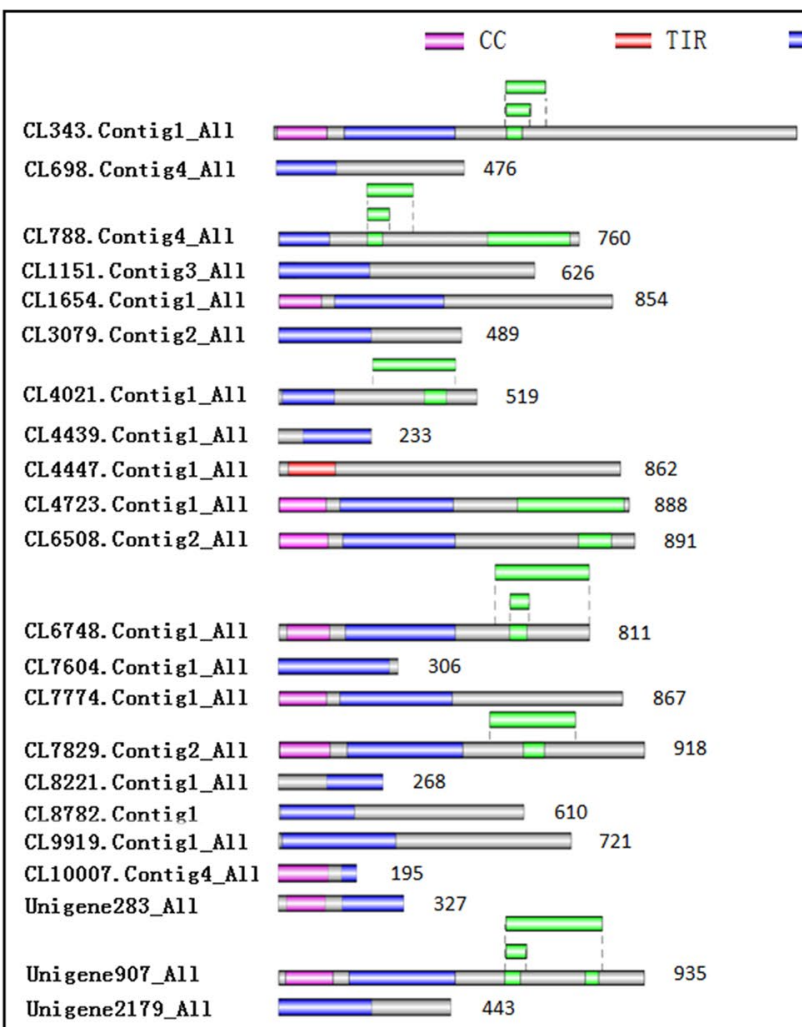

b

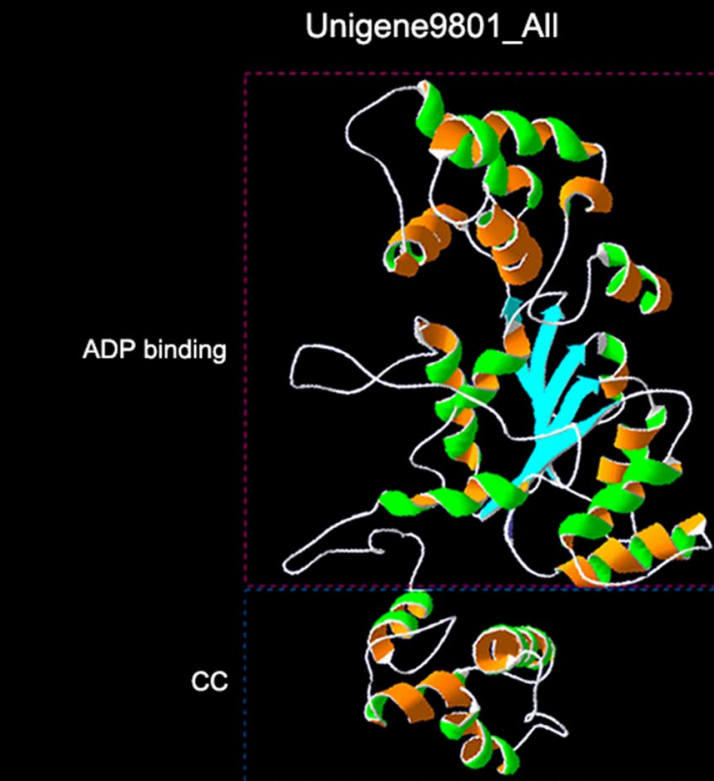

$=\mathrm{NB}^{\mathrm{ARC}}=\mathrm{LRR}$

Unigene2278_Al1 1310 Unigene4299_All

Unigene4345_All

Unigene4363_Al1

Unigene6172_Al1

Unigene6303_All

Unigene7113_All

Unigene7646_Al1

Unigene7647_All

Unigene7657_All

Unigene9801_Al1

Unigene10109_All

Unigene12365_All

Unigene12477_A11
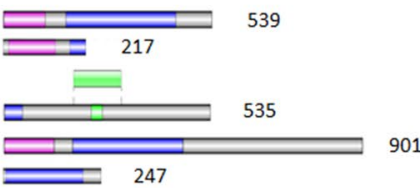

$=226$
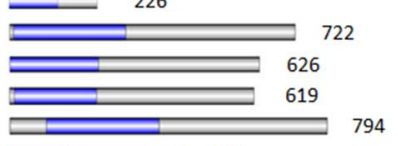

$=435$

$=334$

$\begin{array}{ll}\square 20 & \\ \square & \end{array}$

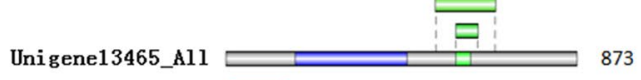

Unigene13465_A11

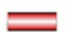

Unigene13744_Al1 $=251$

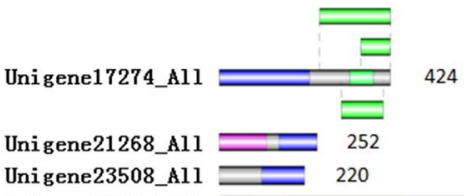

Unigene23508_Al1

Unigene25475_All

Unigene25774_Al1

Unigene26135_All

Unigene26472_Al1

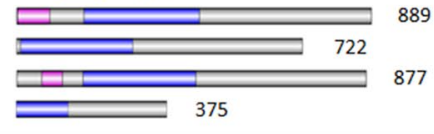

\section{Unigene25774_All}

ADP binding

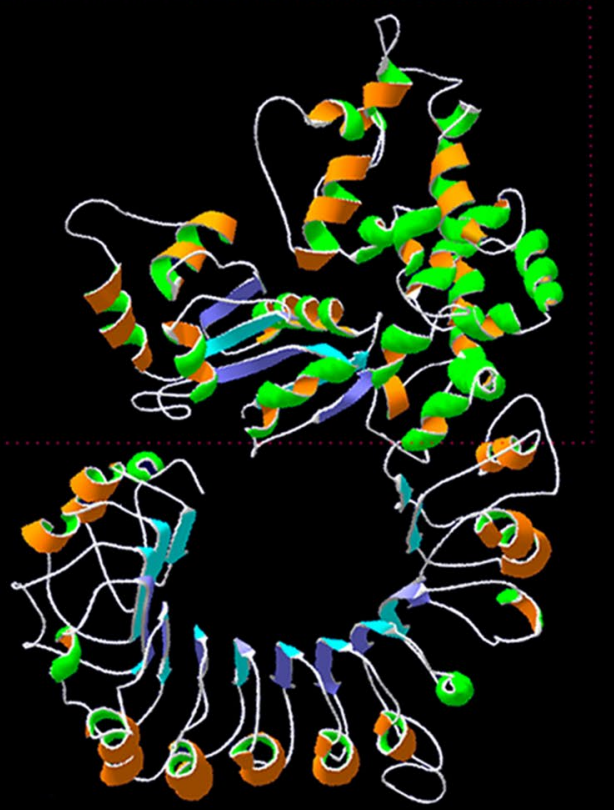

Fig. 1 Schematic diagram of the NB-ARC protein conserved domain in $R$. glutinosa. a Four putative domains are represented by a number on the coloured box. Names of all members and domain sizes are pre- sented on the left and right side of the figure, respectively. b Tertiary structure of two representative NB-ARC proteins Unigene9801_All and Unigene25774_All 


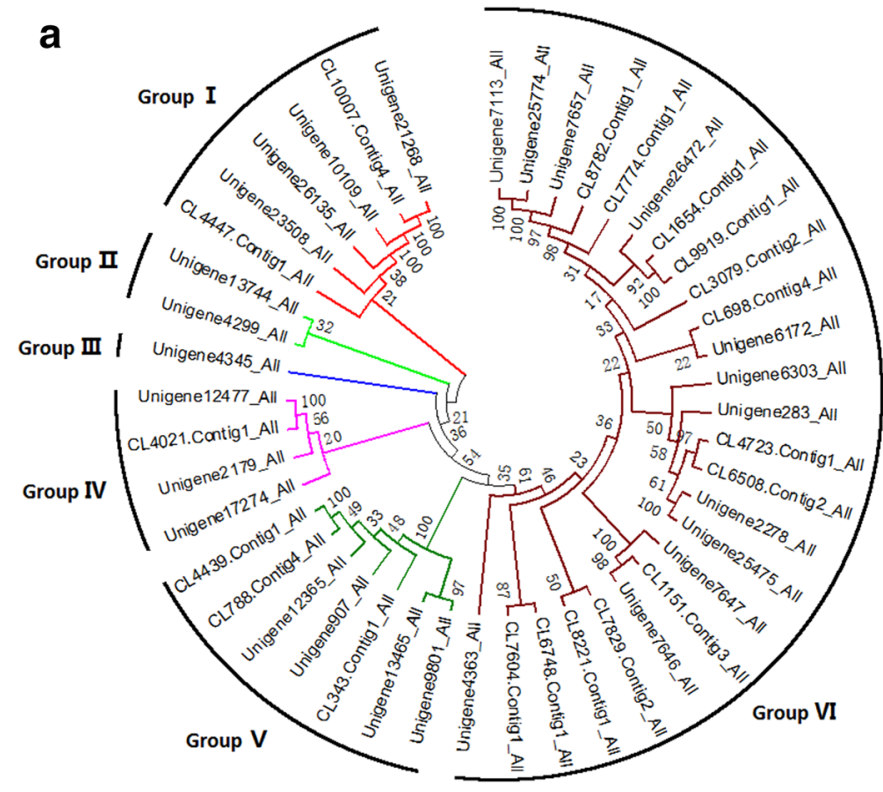

Fig. 2 Phylogenetic tree of $R$. glutinosa NB-ARC protein sequences. Phylogenetic trees of NB-ARC sequences were constructed using the MEGA 6.06 tool. Unrooted neighbour-joining analysis was performed with pairwise deletion and Poisson correction, and the bootstrap values are presented at the corresponding nodes. The same

The results showed that SP, FA and FO treatments could induce the up-regulated expression of $N B-A R C$ genes, but the induction pattern of $N B-A R C$ genes by SP treatment was similar to that by FO treatment. Therefore, $N B-A R C$ genes in ETI system were involved in the formation of $R$. glutinosa consecutive monoculture problems.

\section{Discussion}

In $R$. glutinosa, consecutive monoculture problems occur in the second year after planting (Zhang et al. 2011). Previous studies have indicated that phenolic acids in root exudates are important allelopathic autotoxins (Li et al. 2012). However, phenolic acids are degraded by soil microorganisms within a week in the field (Zhang et al. 2010). The addition of phenolic acids caused significant increases in the population of pathogenic microorganisms in plate cultures and field experiments (Wu et al. 2017; Zhang et al. 2016). Allelochemicals of root exudates mediated adverse chemotaxis of rhizospheric microbes (Wu et al. 2015; Zhang et al. 2013). The immune systems of $R$. glutinosa are activated and finally compromised due to continuous attack by a large number of proliferating pathogens. (Li et al. 2017). qRT-PCR analysis further demonstrated that $N B-A R C$ genes in ETI system are employed in the formation of $R$. glutinosa consecutive monoculture problems.

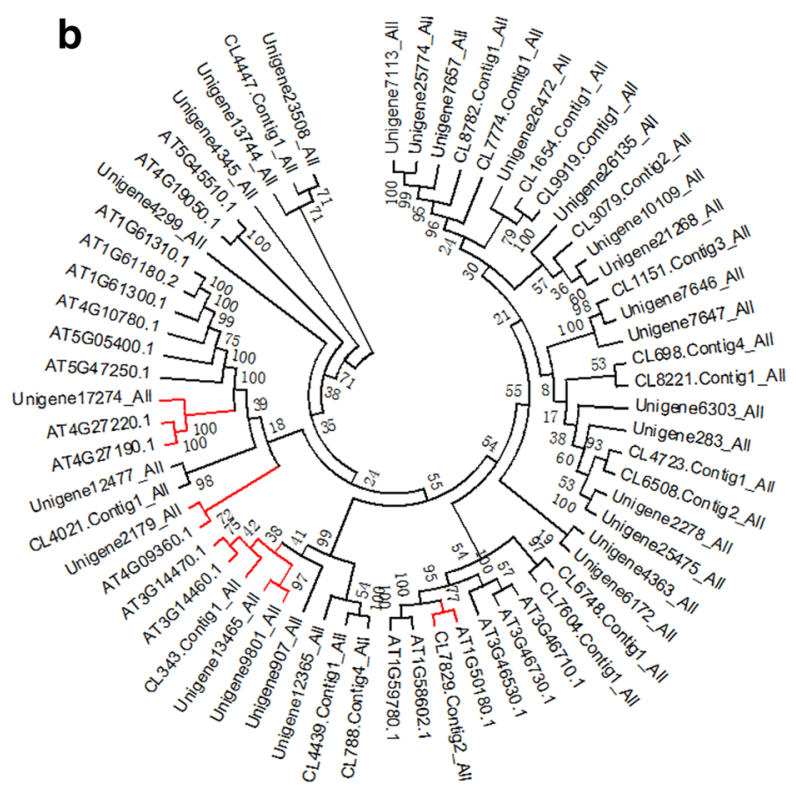

colour represents the same type of homology. a Homology analyses for 45 NB-ARC proteins of $R$. glutinosa. b Homology analyses for 45 NB-ARC proteins of $R$. glutinosa and alignment with Arabidopsis thaliana, in which $R$. glutinosa NB-ARCs remarked by red-coloured line have closely homology with that of A. Thaliana

In the ETI system, the effector is recognized by an NBARC protein based on direct and indirect recognizing models (Sekhwal et al. 2015). In NB-ARC proteins, R1A (resistance in linkage group 1A), R1B and RPP13 (resistance to Peronospora parasitica 13) can directly recognize effectors (Birch et al. 2008; Du et al. 2015; Kuang et al. 2005; Sekhwal et al. 2015). RPM1 (resistance to pseudomonas syringae pv maculicola), RPS5 (resistance to pseudomonas syringae 5), Prf (for Pseudomonas resistance and fenthion sensitivity), RGA (Rx-like proteins), RPS2, TAO1 (target of AvrB operation), RPS4, RPS6, SNC1 (suppressor of npr11 , constitutive 1) and RPP13 indirectly recognize effectors through interactions with target proteins of RIN4 (RPM1interacting protein 4), PBS1 (AvrPphB susceptible1), Pto (for Pseudomonas syringae pv. tomato), RanGAP2 (Ran GTPase-activating protein) and EDS1 (Bittner-Eddy et al. 2000, 2001; Chen et al. 2014; Eitas et al. 2008; Khan et al. 2016; Sacco et al. 2007; Sekhwal et al. 2015; Song et al. 2003; Sun et al. 2013; Zentella et al. 2007). The results of homologous cluster with $R$. glutinosa and Arabidopsis thaliana in phylogenetic tree showed that six NB-ARC proteins are closely related to disease resistance. Abnormal growth and death occur in consecutive monocultures of R. glutinosa. According to functional predictions, the 45 identified NBARC protein sequences in $R$. glutinosa included R1A, R1B, RGA, RPP13, RPM1 and TAO1.

Previous studies have revealed that the expression of pathogenic effectors is closely related to the stage and 


\section{a}
0.0
10.0
20.0

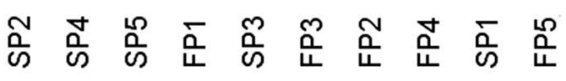

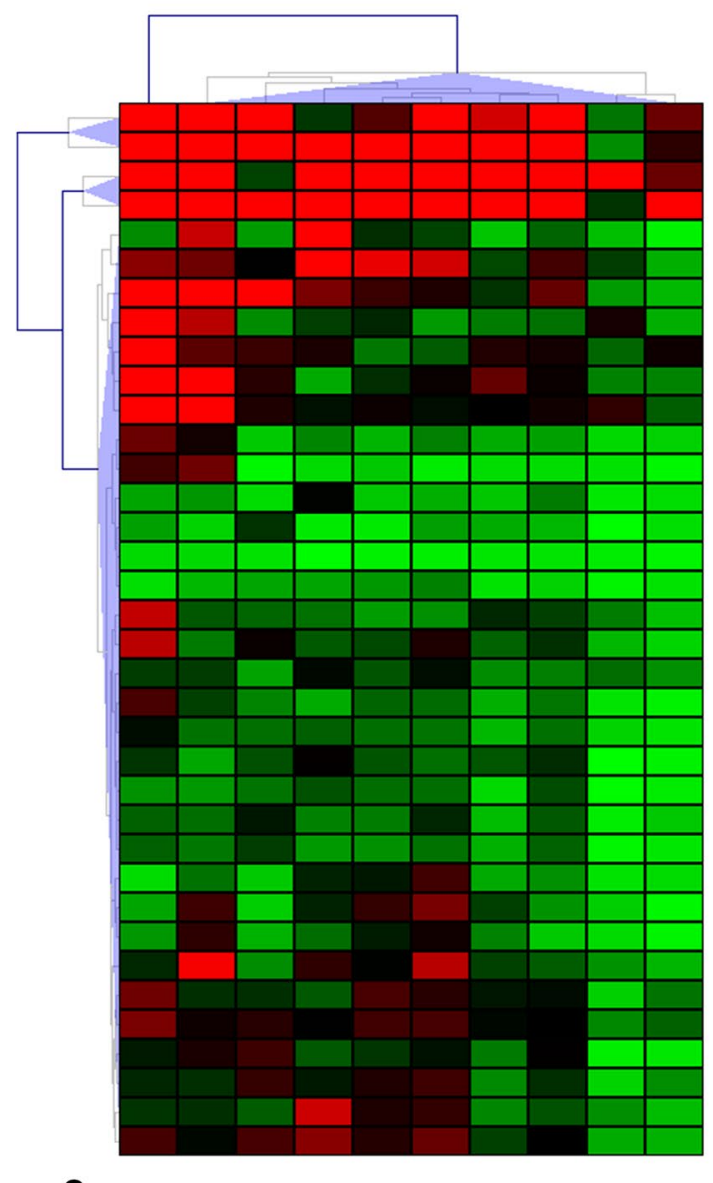

b

Unigene12477_All Unigene907 AII Unigene $254 \overline{7} 5$ All CL4439.Contig 1 All Unigene26135_Āll CL7829. Contig2 All Unigene4345_All Unigene283 Âll Unigene $123 \overline{6} 5$ All CL8221.Contig1_All CL4723.Contig 1 All Unigene4363 AlI CL6748.Contig1_All Unigene6303_AlI Unigene6172-All Unigene2577 $\overline{4}$ All CL4021.Contig 1 _All Unigene7113_AlI Unigene2179_All CL4447.Contig1 All Unigene26472 All Unigene7657_ÂA Unigene9801-All Unigene 7647-All

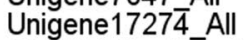
CL1654.Contig 1_All Unigene7646_AII Unigene 1010̄̄_All CL3079.Contiḡ2_All CL8782.Contig1-All Unigene2278 AlI CL6508.Contig2_All CL9919.Contig1_All CL788.Contig4 Âll Unigene13465_All CL698.Contig4 All

\begin{tabular}{|c|c|c|c|}
\hline$\frac{-2.0}{\frac{0}{\mathbf{c}}}$ & 은 & $\begin{array}{l}0.0 \\
\text { ญ } \\
\frac{1}{\text { \% }} \\
\frac{0}{0}\end{array}$ & $\begin{array}{l}\frac{+}{0} \\
\frac{1}{5} \\
\frac{1}{5}\end{array}$ \\
\hline
\end{tabular}

C
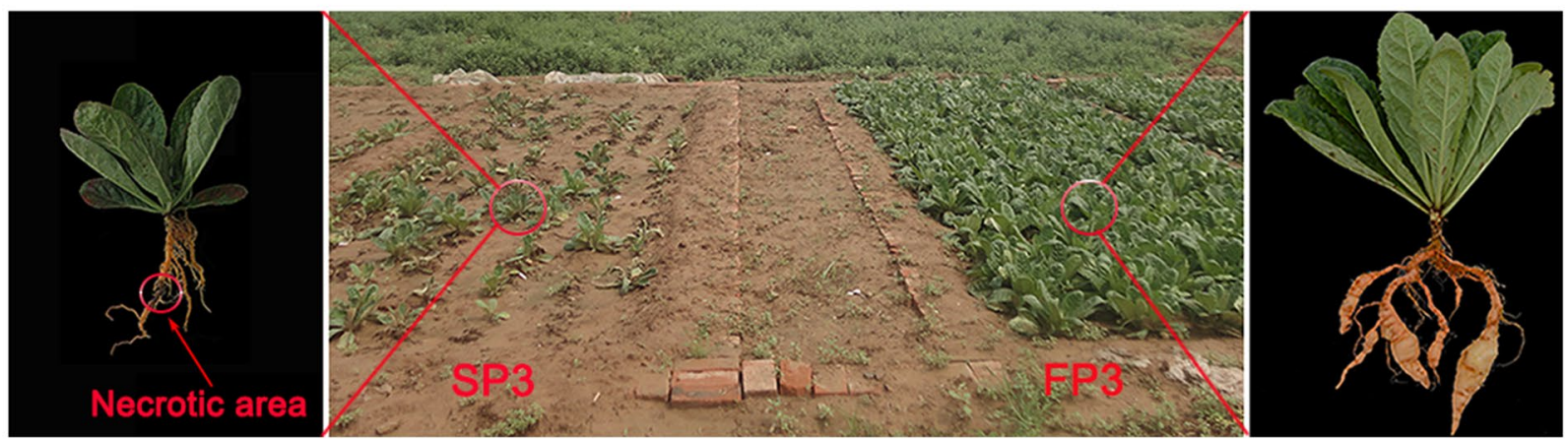

Fig. 3 Expression profiles of 36 expressed $N B-A R C$ genes at different developmental stages in $R$. glutinosa. a Expression levels (RPKM, reads per kilobase per million mapped reads). b Ratios of expression levels. The colour bar presents the gene expression levels. Green indicates low expression, whereas red indicates high expression. Black indicates minimal difference in expression. The five samples represented sampling times of 30,60, 90, 120, and 150 days after planting. The heat maps were created using MeV 4.9.0 software. $\mathbf{c}$ Phenotypes of first-year (left) and second-year (right) $R$. glutinosa plants 90 days after planting 

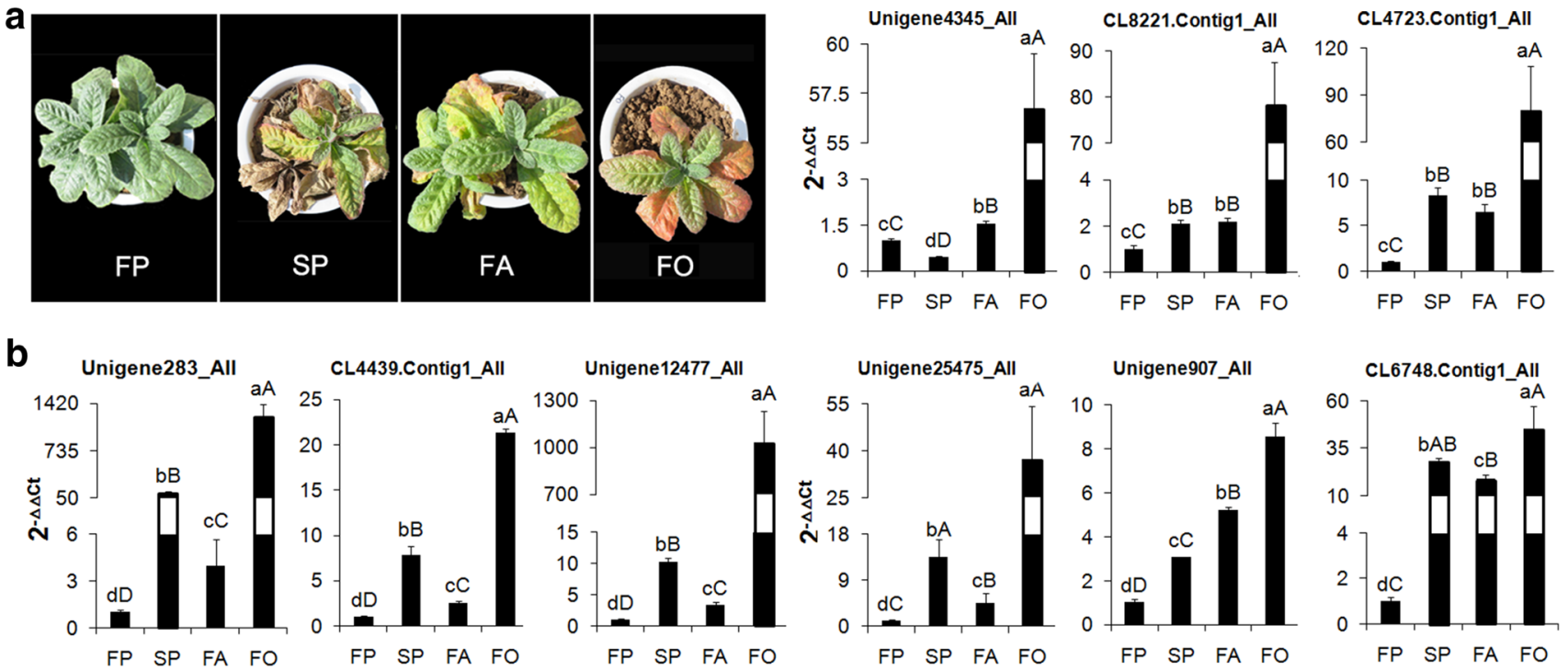

Fig. 4 Nine randomly selected up-regulated $N B-A R C$ genes responding to different stress factors involved in the formation of consecutive monoculture problems. a Phenotypes of the four different treatments FP, SP, FA and FO. b Gene expression levels of the different treatments. FO treatment caused the most significant increases in $N B-A R C$ gene expression levels followed by SP and FA treatments. Values are

location of infection (Toruño et al. 2016). For example, the specific effectors, $C$. higginsianum effectors, either inhibit or promote cell death after undergoing threefold increase of expression during infection of Colletotrichum higginsianum in Arabidopsis (Kleemann et al. 2012). Furthermore, disorder expression of stage-specific effectors significantly reduced Phytophthora sojae virulence in N. benthamiana and soybean (Wang et al. 2011). In addition, successful expression of Ustilago maydis effectors only occurred in the colonized maize organ (Schilling et al. 2014). Therefore, a correct time and place is required when ETI system performs immune function (Smith et al. 2014). Previous studies have demonstrated that immune resistance disorder resulted from inappropriate NB-ARC protein activation (Rodriguez et al. 2015). In this study, the $N B-A R C$ genes expression was obviously up-regulated by $91.67 \%$ in SP2 stage, and serious death was correspondingly occurred (Fig. 3). The results suggested that consecutive monoculture stress inappropriately triggered $N B-A R C$ gene expression, leading to immune response disorders in $R$. glutinosa. qRT-PCR analysis indicated that similar expression patterns of $N B-A R C$ genes were

Table 2 Pearson correlation matrix visualizing $N B-A R C$ genes ranked by three different treatments

\begin{tabular}{llll}
\hline & SP & FA & FO \\
\hline SP & 1 & 0.0801 & $0.7067^{* *}$ \\
FA & & 1 & -0.1690 \\
FO & & & 1 \\
\hline
\end{tabular}

$* * P<0.01$

presented as the means $\pm \mathrm{SD}$. Lower-case letters indicate significant differences $(P<0.05 ; t$ test), and capital letters indicate significant differences $(P<0.01 ; t$ test). $F P$ first-year plant, $S P$ second-year plant, $F A$ ferulic acid stress, $F O$ stress of Fusarium invasion (Fusarium oxysporum f.sp. R. glutinosa)

observed in SP and FO stress. A possible depict for NB-ARC in ETI-mediated consecutive monoculture stress is presented in Fig. 5.

We have unravelled the protein structures, phylogenies, and gene expression patterns of NB-ARC family proteins in $R$. glutinosa. These findings provide insights into the mechanism of formation of consecutive monoculture problems. Moreover, $N B-A R C$ genes exhibit molecular polymorphisms. In nature, long-lived plants can renew their composition and ratio of resistance genes (Deng et al. 2017; Kong et al. 2017; Quintin et al. 2014; Santhanam et al. 2015; Tena 2016; Tobias and Guest 2014; Wei et al. 2015). With the development of biotechnological techniques and the modification of resistance genes, some researchers can improve the recognition of pathogen effectors using random single amino acid mutations or protein modification of NB-ARC sequences (Segretin et al. 2014; Wang et al. 2015). These new findings will provide a new method for resolving consecutive monoculture problems in the future.

\section{Conclusions}

The present study identified 45 NB-ARC protein sequences in $R$. glutinosa and described their corresponding functions, structures and phylogenetic traits. At same time, $N B$ $A R C$ genes were found to be involved in the formation of $R$. glutinosa consecutive monoculture problems that 


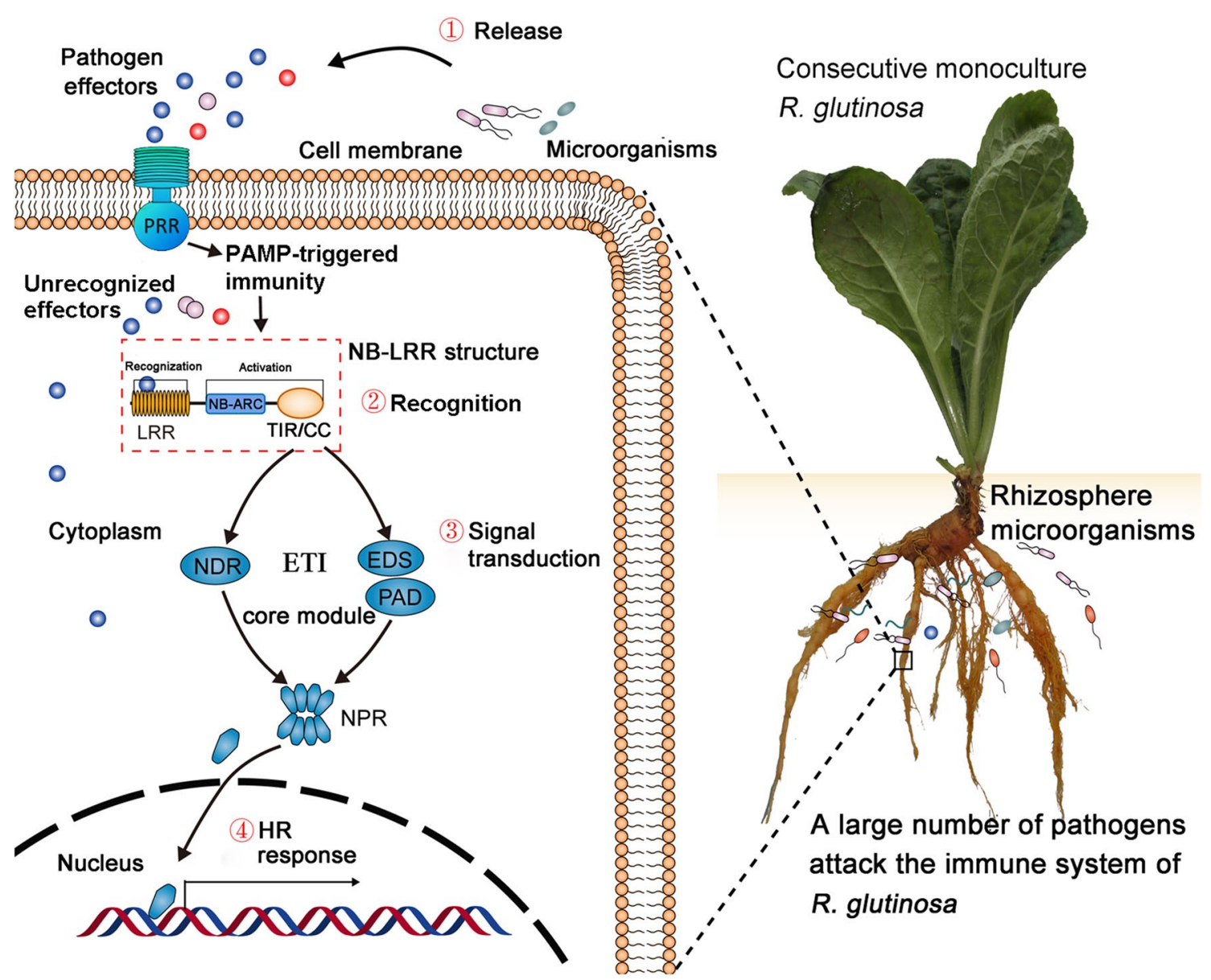

Fig. 5 Sketch map for effector-triggered immunity mediated by consecutive monoculture stress in $R$. glutinosa. A typical ETI system includes NB-ARC, NDR/EDS, and NPR core proteins, in which NB-ARC might recognize effectors from pathogens. NB-ARC protein is thus a critical protein that functions in the ETI system. Allelochemicals released from consecutive monocultures of $R$. glutinosa significantly induce pathogen proliferation. Various effectors from these pathogens are thus continuously released into rhizosphere soils

are rarely expressed 30 days after planting and frequently expressed at approximately 60 days after planting. The findings of this study provide insights into the mechanism of formation of consecutive monoculture problems.

Author contribution statement Conceived and designed the experiments: ML. Performed the experiments: AC, LG, NX, GL, FF, and BZ. Analysed the data and wrote the manuscript: AC, LG, ML, DG, JZ, and HL. Supervisory support: $\mathrm{ZZ}$. All the authors have read and approved the final content of the manuscript.

Acknowledgements In this study, the protein information and the other support data were derived from correspondence author Prof. Zhang Zhongyi, my PhD supervisor in Fujian Agriculture and Forestry under consecutive monoculture stress. Some effectors might trick the PTI system and successfully enter the cytoplasm. To eliminate these attacks from pathogens as soon as possible, plants can effectively recognize these effectors based on the LRR domain of NB-ARC protein. For a large number of pathogens induced by allelochemicals in consecutive monocultures of $R$. glutinosa, numerous effectors are produced that continuously attack $R$. glutinosa and ultimately result in loss of the recognition ability of the ETI

University. We gratefully acknowledge all members of Zhang Zhongyi research group.

Funding This study was supported by the National Natural Science Foundation of China (Grant No. 81503193, 81573538, 81603243 and 81403042) and the Key Scientific Research Project of the higher Education Institutions of Fujian Province of China (No. JK2015013).

Open Access This article is distributed under the terms of the Creative Commons Attribution 4.0 International License (http://creativeco mmons.org/licenses/by/4.0/), which permits unrestricted use, distribution, and reproduction in any medium, provided you give appropriate credit to the original author(s) and the source, provide a link to the Creative Commons license, and indicate if changes were made. 


\section{References}

Bigeard J, Colcombet J, Hirt H (2015) Signaling mechanisms in pattern-triggered immunity (PTI). Mol Plant 8:521-539. https://doi. org/10.1016/j.molp.2014.12.022

Birch PRJ, Boevink PC, Gilroy EM, Hein I, Pritchard L, Whisson S (2008) Oomycete RXLR effectors: delivery, functional redundancy and durable disease resistance. Curr Opin Plant Biol 11:373-379. https://doi.org/10.1016/j.pbi.2008.04.005

Bittner-Eddy PD, Beynon JL (2001) The Arabidopsis Downy Mildew Resistance Gene. RPP 13-Nd, functions independently of NDR1 and EDS1 and does not require the accumulation of salicylic acid. Mol Plant Microbe In 14:416-421. https://doi. org/10.1094/MPMI.2001.14.3.416

Bittner-Eddy PD, Crute IR, Holub EB, Beynon JL (2000) RPP13 is a simple locus in Arabidopsis thaliana for alleles that specify downy mildew resistance to different avirulence determinants in Peronospora parasitica. Plant J 21:177-188. https://doi. org/10.1046/j.1365-313x.2000.00664.X

Chen MX, Maodzeka A, Zhou LH, Ali E, Wang Z, Jiang LX (2014) Removal of DELLA repression promotes leaf senescence in Arabidopsis. Plant Sci 219-220:26-34. https://doi. org/10.1016/j.plantsci.2013.11.016

Deng YW, Zhai KR, Xie Z, Yang DY, Zhu XD, Liu JZ, Wang X, Qin P, Yang YZ, Zhang GM, Li Q, Zhang JF, Wu SQ, Milazzo J, Mao BZ, Wang ET, Xie HA, Tharreau D, He ZH (2017) Epigenetic regulation of antagonistic receptors confers rice blast resistance with yield balance. Science 355:962-965. https://doi.org/10.1126/ science.aai8898

Dodds PN, Rathjen JP (2010) Plant immunity: towards an integrated view of plant-pathogen interactions. Nat Rev Genet 11:539-548. https://doi.org/10.1038/nrg2812

Du Y, Berg J, Govers F, Bouwmeester K (2015) Immune activation mediated by the late blight resistance protein $\mathrm{R} 1$ requires nuclear localization of R1 and the effector AVR1. New Phytol 207:735747. https://doi.org/10.1111/nph.13355

Eitas TK, Nimchuk ZL, Dangl JL (2008) Arabidopsis TAO1 is a TIRNB-LRR protein that contributes to disease resistance induced by the Pseudomonas syringae effector AvrB. P Natl Acad Sci USA 105:6475-6480. https://doi.org/10.1073/pnas.0802157105

Finn RD, Clements J, Arndt W, Miller BL, Wheeler TJ, Schreiber F, Bateman A, Eddy SR (2015) HMMER web server: 2015 update. Nucleic Acids Res 43:30-38. https://doi.org/10.1093/nar/gkv397

Gassmann W, Bhattacharjee S (2012) Effector-triggered immunity signaling: from gene-for-gene pathways to protein-protein interaction networks. Mol Plant Microbe In 25:862-868. https://doi. org/10.1094/MPMI-01-12-0024-IA

Groll M, Schellenberg B, Bachmann AS, Archer CR, Huber R, Powell TK, Lindow S, Kaiser M, Dudler R (2008) A plant pathogen virulence factor inhibits the eukaryotic proteasome by a novel mechanism. Nature 452:755-758. https://doi.org/10.1038/nature06782

Guex N, Peitsch MC (1997) SWISS-MODEL and the Swiss-pdb viewer: an environment for comparative protein modeling. Electrophoresis 18:2714-2723. https://doi.org/10.1002/elps.11501 81505

Jones JDG, Dangl JL (2006) The plant immune system. Nature 444:323-329. https://doi.org/10.1038/nature05286

Khan M, Subramaniam R, Desveaux D (2016) Of guards, decoys, baits and traps: pathogen perception in plants by type III effector sensors. Curr Opin Microbiol 29:49-55. https://doi.org/10.1016/j. mib.2015.10.006

Kleemann J, Rincon-Rivera LJ, Takahara H, Neumann U, Ver Loren van Themaat E, Charlotte van der Does H, Hacquard S, Stüber K, Will I, Schmalenbach W, Schmelzer E, O'Connell1 RJ (2012) Sequential delivery of host-induced virulence effectors by appressoria and intracellular hyphae of the phytopathogen Colle totrichum higginsianum. PLoS Pathog 8(4):e1002643. https://doi. org/10.1371/journal.ppat.1002643

Kobayashi M, Nagasaki H, Garcia V, Just D, Bres C, Mauxion JP, Paslier MC, Brunel D, Suda K, Minakuchi Y, Toyoda A, Fujiyama A, Toyoshima H, Suzuki T, Igarashi K, Rothan C, Kaminuma E, Nakamura Y, Yano K, Aoki K (2014) Genome-wide analysis of intraspecifc DNA polymorphism in 'Micro-Tom', a model cultivar of tomato (Solanum lycopersicum). Plant Cell Physiol 55:445-454. https://doi.org/10.1093/pcp/pct181

Kong L, Qiu XF, Kang JG, Wang Y, Chen H, Huang J, Qiu M, Zhao Y, Kong GH, Ma ZC, Wang Y, Ye WW, Dong SM, Ma WB, Wang YC (2017) A Phytophthora effector manipulates host histone acetylation and reprograms defense gene expression to promote infection. Curr Biol 27:1-11. https://doi.org/10.1016/j.cub.2017.02.044

Kuang HH, Wei FS, Marano MR, Wirtz U, Wang XX, Liu J, Shum WP, Zaborsky J, Tallon LJ, Rensink W, Lobst S, Zhang PF, Tornqvist CE, Tek A, Bamberg J, Helgeson J, Fry W, You F, Luo MC, Jiang JM, Buell R, Baker B (2005) The Rl resistance gene cluster contains three groups of independently evolving, type I $R 1$ homologues and shows substantial structural variation among haplotypes of Solanum demissum. Plant J 44:37-51. https://doi. org/10.1111/j.1365-313X.2005.02506.X

Kushalappa AC, Yogendra KN, Karre S (2016) Plant innate immune response: qualitative and quantitative resistance. Crit Rev Plant Sci 35:38-55. https://doi.org/10.1080/07352689.2016.1148980

Li ZF, Yang YH, Xie DF, Zhu LF, Zhang ZG, Lin WX (2012) Identification of autotoxic compounds in fibrous roots of Rehmannia (Rehmannia glutinosa Libosch.). Plos One 7:e28806. https://doi. org/10.1371/journal.pone.0028806

Li MJ, Yang YH, Chen XJ, Wang FQ, Lin WX, Yi YJ, Zeng L, Yang SY, Zhang ZY (2013) Transcriptome/degradome-wide identification of $R$. glutinosa miRNAs and their targets: the role of miRNA activity in the replanting disease. PLoS One 8:e68531. https://doi. org/10.1371/journal.pone.0068531

Li MJ, Yang YH, Li XY, Gu L, Wang FJ, Feng FJ, Tian YH, Wang FQ, Wang XR, Lin WX, Chen XJ, Zhang ZY (2015) Analysis of integrated multiple 'omics' datasets reveals the initiation and determination mechanisms of tuberous root formation in $R$. glutinosa. J Exp Bot 66:5837. https://doi.org/10.1093/jxb/erv288

Li MJ, Yang YH, Feng FJ, Zhang B, Chen SQ, Yang CY, Gu L, Wang FQ, Zhang JY, Chen AG, Lin WX, Chen XJ, Zhang ZY (2017) Differential proteomic analysis of replanted Rehmannia glutinosa roots by iTRAQ reveals molecular mechanisms for formation of replant disease. BMC Plant Biol 17:116. https://doi.org/10.1186/ s12870-017-1060-0

Lin WX, Fang CX, Wu LK, Lin S (2016) Research on and application of rice allelopathy and crop allelopathic autotoxicity in China. In: Luo SM, Gliessman SR (eds) Agroecology in China: science, practice, and sustainable management. CRC Press, Boca Raton, pp 161-196

Liu WZ, Xie YB, Ma JY, Luo XT, Nie P, Zuo ZX, Lahrmann U, Zhao Q, Zheng YY, Zhao Y, Xue Y, Ren J (2015) IBS: an illustrator for the presentation and visualization of biological sequences. Bioinformatics 31:3359-3361. https://doi.org/10.1093/bioinforma tics/btv362

Livak KJ, Schmittgen TD (2001) Analysis of relative gene expression data using real-time quantitative PCR and the 2(-Delta Delta C (T)). Methods 25:402-408. https://doi.org/10.1006/ meth.2001.1262

Ma LS, Burg HAVD., Cornelissen BJC, Takken FLW (2013) Molecular basis of effector recognition by plant NB-LRR proteins. In: Sessa G (ed) Molecular plant immunity. John Wiley \& Sons, Inc, Ames, pp 23-40

Marchler-Bauer A, Bo Y, Han LY, He J, Lanczycki CJ, Lu S, Chitsaz F, Derbyshire MK, Geer RC, Gonzales NR, Gwadz M, Hurwitz 
DI, Lu F, Marchler GH, Song JS, Thanki N, Wang ZX, Yamashita RA, Zhang DC, Zheng CJ, Geer LY, Bryant SH (2017) CDD/ SPARCLE: functional classification of proteins via subfamily domain architectures. Nucleic Acids Res 45:200-203. https://doi. org/10.1093/nar/gkw1129

Marone M, Russo MA, Laidò G, Leonardis AMD, Mastrangelo AM (2013) Plant nucleotide binding site-leucine-rich repeat (NBSLRR) genes: active guardians in host defense responses. Int J Mol Sci 14:7302-7326. https://doi.org/10.3390/ijms14047302

Mortazavi A, Williams BA, McCue K, Schaeffer L, Wold B (2008) Mapping and quantifying mammalian transcriptomes by RNASEq. Nat Methods 5:621-628. https://doi.org/10.1038/nmeth.1226

Pajerowska-Mukhtar KM, Emerine DK, Mukhtar MS (2013) Tell me more: roles of NPRs in plant immunity. Trends Plant Sci 18:402411. https://doi.org/10.1016/j.tplants.2013.04.004

Quintin J, Cheng SC, Meer JW, Netea MG (2014) Innate immune memory: towards a better understanding of host defense mechanisms. Curr Opin Immunol 29:1-7. https://doi.org/10.1016/j. coi.2014.02.006

Rodriguez E, Ghoul HE, Mundy J, Petersen M (2015) Making sense of plant autoimmunity and 'negative regulators'. FEBS J 283:13851391. https://doi.org/10.1111/febs.13613

Sacco MA, Mansoor S, Moffett P (2007) A RanGAP protein physically interacts with the NB-LRR protein $\mathrm{Rx}$, and is required for Rx-mediated viral resistance. Plant J 52:82-93. https://doi. org/10.1111/j.1365-313X.2007.03213.x

Saeed AI, Bhagabati NK, Braisted JC, Liang W, Sharov V, Howe EA, Li JW, Thiagarajan M, White JA, Quackenbush J (2006) TM4 microarray software suite. Method Enzymol 411:134-193. https ://doi.org/10.1016/S0076-6879(06)11009-5

Santhanam R, Luu VT, Weinhold A, Goldberg J, Oh Y, Baldwin LT (2015) Native root-associated bacteria rescue a plant from a sudden-wilt disease that emerged during continuous cropping. P Natl Acad Sci USA 112:5013-5020. https://doi.org/10.1073/ pnas. 1505765112

Schilling L, Matei A, Redkar A, Walbot V, Doehlemann G (2014) Virulence of the maize smut Ustilago maydis is shaped by organspecific effectors. Mol Plant Pathol 15(8):780-789. https://doi. org/10.1111/mpp.12133

Segretin ME, Pais M, Franceschetti M, Chaparro-Garcia A, Bos J, Banfield MJ, Kamoun S (2014) Single amino acid mutations in the potato immune receptor R3a expand response to Phytophthora effectors. Mol Plant Microbe In 27:624-637. https://doi. org/10.1094/MPMI-02-14-0040-R

Sekhwal MK, Li PC, Lam I, Wang X, Cloutier S, You FM (2015) Disease resistance gene analogs (RGAs) in plants. Int J Mol Sci 16(8):19248-19290. https://doi.org/10.3390/ijms160819248

Smith JM, Leslie ME, Robinson SJ, Korasick DA, Zhang T, Backues SK, Cornish PV, Koo AJ, Bednarek SY, Heese A (2014) Loss of Arabidopsis thaliana dynamin-related protein $2 \mathrm{~B}$ reveals separation of innate immune signaling pathways. PLoS Pathog 10:e1004578. https://doi.org/10.1371/journal.ppat.1004578

Song JQ, Bradeen JM, Naess SK, Raasch JA, Wielgus SM, Haberlach G, Liu J, Kuang HH, Austin-Phillips S, Buell CR, Helgeson JP, Jiang JM (2003) Gene RB cloned from Solanum bulbocastanum confers broad spectrum resistance to potato late blight. $\mathrm{P}$ Natl Acad Sci USA 100:9128-9133. https://doi.org/10.1073/ pnas. 1533501100

Stael S, Kmiecik P, Willems P, Kelen KVD, Coll NS, Teige M, Breusegem FV (2015) Plant innate immunity-sunny side up? Trends Plant Sci 20:3-11. https://doi.org/10.1016/j.tplan ts.2014.10.002

Sun H, Huang LM, Huang LQ, Guo LP, Zhou J, Lv DM, Zeng Y (2008) Study on medicinal plant allelopathy and soil sickness based on ecological niche. Chin J Chin Mater Med 33:2197-2200. https://doi.org/10.3321/j.issn:1001-5302.2008.17.038
Sun YD, Li L, Macho AP, Han ZF, Hu ZH, Zipfel C, Zhou JM, Chai JJ (2013) Structural basis for flg22-induced activation of the Arabidopsis FLS2-BAK1 immune complex. Science 342:624-628. https://doi.org/10.1126/science.1243825

Tamura K, Stecher G, Peterson D, Filipski A, Kumar S (2013) MEGA6: molecular evolutionary genetics analysis version 6.0. Mol Biol Evol 30:2725-2729. https://doi.org/10.1093/molbev/mst197

Tena G (2016) Immunity: NLR population control. Nat Plants 2:16026. https://doi.org/10.1038/nplants.2016.26

Thomma BPHJ., Nürnberger T, Joosten MHAJ. (2011) Of PAMPs and effectors: the blurred PTI-ETI dichotomy. Plant Cell 23:4-15. https://doi.org/10.1105/tpc.110.082602

Tian YH, Feng FJ, Zhang B, Li MJ, Wang FQ, Gu L, Chen AG, Li ZJ, Shan WB, Wang XR, Chen XJ, Zhang ZY (2017) Transcriptome analysis reveals metabolic alteration due to consecutive monoculture and abiotic stress stimuli in Rehmannia glutinosa Libosch. Plant Cell Rep 36:859-875. https://doi.org/10.1007/ s00299-017-2115-2

Tobias PA, Guest DI (2014) Tree immunity: growing old without antibodies. Trends Plant Sci 19:367-370. https://doi.org/10.1016/j. tplants.2014.01.011

Toruño TY, Stergiopoulos I, Coaker G (2016) Plant-pathogen effectors: cellular probes interfering with plant defenses in spatial and temporal manners. Annu Rev Phytopathol 54:419-441. https:// doi.org/10.1146/annurev-phyto-080615-100204

Wang QQ, Han CZ, Ferreira AO, Yu XL, Ye WW, Tripathy S, Kale SD, Gu B, Sheng YT, Sui YY, Wang XL, Zhang ZG, Cheng BP, Dong SM, Shan WX, Zheng XB, Dou DL, Tyler BM, Wang YC (2011) Transcriptional programming and functional interactions within the Phytophthora sojae RXLR effector repertoire. Plant Cell 23:2064-2086. https://doi.org/10.1105/tpc.111.086082

Wang GX, Roux B, Feng F, Guy E, Li L, Li NN, Zhang XJ, Lautier M, Jardinaud MF, Chabannes M, Arlat M, Chen S, He CZ, Noël LD, Zhou JM (2015) The decoy substrate of a pathogen effector and a pseudokinase specify pathogen-induced modified-self recognition and immunity in plants. Cell Host Microbe 18:285-295. https:// doi.org/10.1016/j.chom.2015.08.004

Wei W, Xu YL, Li SX, Zhu L, Song J (2015) Developing suppressive soil for root diseases of soybean with continuous long-term cropping of soybean in black soil of Northeast China. Acta Agr Scand B-S P 65:279-285. https://doi.org/10.1080/09064710.2014.99294 1

Wen XS, Li XE, Yang SL (2001) Viral diseases of Rehmannia glutinosa and problems demanding prompt solution. Chin Tradit Herb Drugs 32:662-664. https://doi.org/10.3321/j. issn:0253-2670.2001.07.046

Wen XS, Yang SL, Wei JH, Zheng JH (2002) Textual research on planting history of Rehmannia glutinosa and its cultivated varieties. Chin Tradit Herb Drugs 33:946-949. https://doi.org/10.3321/j. issn:0253-2670

Wu LK, Li ZF, Li J (2013) Assessment of shifts in microbial community structure and catabolic diversity in response to Rehmannia glutinosa monoculture. Appl Soil Ecol 67:1-9. https://doi. org/10.1016/j.apsoil.2013.02.008

Wu LK, Wang JY, Huang WM, Wu HM, Chen J, Yang YQ, Zhang ZY, Lin WX (2015) Plant-microbe rhizosphere interactions mediated by Rehmannia glutinosa root exudates under consecutive monoculture. Sci Rep UK 5:15871. https://doi.org/10.1038/srep15871

Wu LK, Chen J, Wu HM, Wang JY, Qin XJ, Zhang ZY, Lin WX (2016) Comparative proteomics analysis of $R$. glutinosa tuber root in response to consecutive monoculture. Acta Agron Sin 42:243254. https://doi.org/10.3724/SP.J.1006.2016.00243

Wu HM, Xu JJ, Wang JY, Qin XJ, Wu LK, Li ZC, Lin S, Lin WW, Zhu Q, Khan MU, Lin WX (2017) Insights into the mechanism of proliferation on the special microbes mediated by phenolic acids in the radix pseudostellariae rhizosphere under 
continuous monoculture regimes. Front Plant Sci 8:659. https:// doi.org/10.3389/fpls.2017.00659

Yang YH, Zhang ZY, Fan HM, Zhao YD, Li MJ, Li J, Chen JY, Lin WX, Chen XJ (2013) Construction and analysis of different expression cDNA libraries in Rehmannia glutinosa plants subjected to continuous cropping. Acta Physiol Plant 35:645-655. https://doi.org/10.1007/s11738-012-1105-9

Yang YH, Li MJ, Chen XJ, Wang PF, Wang FQ, Lin WX, Yi YJ, Zhang ZY (2014) De novo characterization of the Rehmannia glutinosa leaf transcriptome and analysis of gene expression associated with replanting disease. Mol Breed 34:905-915. https://doi. org/10.1007/s11032-014-0084-5

Yang YH, Li MJ, Li XY, Chen XJ, Lin WX, Zhang ZY (2015) Transcriptome-wide identification of the genes responding to replanting disease in Rehmannia glutinosa L. roots. Mol Biol Rep 42:881-892. https://doi.org/10.1007/s11033-014-3825-y

Yue JX, Meyers BC, Chen JQ, Tian DC, Yang AH (2011) Tracing the origin and evolutionary history of plant nucleotide-binding site-leucine-rich repeat (NBS-LRR) genes. New Phytol 193:10491063. https://doi.org/10.1111/j.1469-8137.2011.04006.x

Zentella R, Zhang ZL, Park M, Thomas SG, Endo A, Murase K, Fleet CM, Jikumaru Y, Nambara E, Kamiya Y, Sun TP (2007) Global analysis of della direct targets in early gibberellin signaling in
Arabidopsis. Plant Cell 19:3037-3057. https://doi.org/10.1105/ tpc.107.054999

Zhang ZY, Lin WX (2009) Continuous cropping obstacle and allelopathic autotoxicity of medicinal plants. Chin J Eco Agric 17:189196. https://doi.org/10.3724/SP.J.1011.2009.00189

Zhang ZY, Pan LP, Li HH (2010) Isolation, identification and characterization of soil microbes which degrade phenolic allelochemicals. J Appl Microbiol 108:1839-1849. https://doi.org/10.111 1/j.1365-2672.2009.04589.x

Zhang ZY, Lin WX, Yang YH, Chen H, Chen XJ (2011) Effects of consecutively monocultured Rehmannia glutinosa L. on diversity of fungal community in rhizospheric soil. Agr Sci China 10:13741384. https://doi.org/10.1016/S1671-2927(11)60130-2

Zhang ZY, Li MJ, Chen XJ, Wu LK, Li J, Wang FQ, Li ZF, Guo GY, Lin WX (2013) Research advancement and control strategy of consecutive monoculture problem of Rehmannia glutinosa L. Mod Chin Med 15:38-44. https://doi.org/10.13313/j.i ssn.1673-4890.2013.01.003

Zhang B, Li XZ, Wang FQ, Li MJ, Zhang JY, Gu L, Zhang LJ, Tu WQ, Zhang ZY (2016) Assaying the potential autotoxins and microbial community associated with Rehmannia glutinosa replant problems based on its 'autotoxic circle'. Plant soil 407:307-322. https ://doi.org/10.1007/s11104-016-2885-2 